\title{
Teachers' use of inclusive practices in Spain
}

\author{
Esther Chiner \\ and \\ Maria Cristina Cardona \\ University of Alicante, Spain
}

\begin{abstract}
The aim of this study was to examine the extent to which teachers use inclusive practices to respond to students' special needs in their classrooms and to determine whether some variables (grade level taught, training, and availability of resources and support) affect to the implementation of these practices. A research survey was designed for this purpose with the participation of a representative sample of 336 general education teachers (68 kindergarten, 133 elementary, and 135 secondary education teachers) in the province of Alicante, Spain. Findings reflected a moderate use of inclusive practices, with teachers more frequently implementing general adaptations rather than substantial ones. Statistically significant differences in use were found as a function of the grade level taught, training received, and availability of material resources. Results are discussed in terms of their implication for reform of teacher education and training programs.
\end{abstract}

Keywords: inclusive education; inclusive practices; instructional adaptations; special educational needs; general education teachers

\section{Introduction}

The inclusion of students with special educational needs (SENs) in regular classrooms is an international movement which has led many countries that subscribed to its principles, including Spain, to introduce significant changes in their educational systems. Inclusion means changes in legislation, recognizing students' right to participate as active members of the school community and society, and also changes in the school organization (Booth \& Ainscow, 1998; Florian, 1998). In order for inclusion to be a reality, schools must be restructured to address student diversity and promote the full participation of all its members. But the reorganization of schools implies a new 
understanding of education and instruction. General education teachers must face new responsibilities and demands, and how they respond to diversity will be essential for the development of inclusion.

Research suggests (Daane, Beirne-Smith, \& Latham, 2000; Minke, Bear, Deemer, \& Griffin, 1996) that to be effective, inclusion requires not only good convictions (values/beliefs/attitudes and professionalism) but the expertise of teachers in meeting the special needs of diverse groups of students within their own classrooms. However, in practice, teachers have serious instructional concerns related to inclusion and their ability to design and deliver effective instruction for these learners (McLeskey \& Waldron 2002; Scott, Vitale, \& Masten, 1998). Some teachers stress their concern that as more students are included, they will need additional tools and skills. Vaughn, Schumm, Jallad, Slusher, and Saumell (1996) mentioned several aspects which might cause teachers to raise objections to inclusion, such as the large number of students in the class, budget shortages, teachers' work loads, etc. And still others point to the lack of teamwork and ask for guidance in dealing with students with SENs (Daane, BeirneSmith, \& Latham, 2000), or claim that they chose to teach a specific discipline and not special education and, consequently, the inclusion policy forces them to enter areas about which they are unsure or in which they are no interested (Vaughn et al., 1996).

Inclusive practices have been defined as those kind of structures, tasks, and activities which give students real opportunities to participate in the classroom and in the context of the educational community (Chiner, 2011). Tomlinson, Callahan, Tomchin, Eiss, Imbeau, and Landrum (1997) have noted that teachers usually modify or adapt instruction through content (e.g., what is taught to pupils, what materials are used and adapted, how ideas are organized); through process (e.g., ways in which pupils are helped to make sense of key ideas, concepts and skills); and through products (e.g., ways in which pupils show and extend what they have learned). Some of these methods are simply routine or general adaptations, while others can be categorized as specialized adaptations (Fuchs, Fuchs, Hamlett, Phillips, \& Karns, 1995).

Adapting instruction to students' diverse needs seems to be a decisive factor associated with the success of inclusive education (Cardona, 2002; McLeskey \& Waldron, 2002). However, literature shows that teachers do not implement inclusive practices in their classrooms as often as would be expected (e.g., Cardona, 2003a; 
Schumm \& Vaughn, 1991). Bender, Vail, and Scott (1995) carried out a study with a double purpose: (1) to know which teaching strategies general classroom teachers used in their classrooms, and (2) to analyze the existence of a possible relationship between teachers' attitudes towards inclusion and the strategies they implemented. The authors concluded that teachers: (a) do not use certain types of effective teaching strategies to help SENs students' academic achievement; and (b) tend to implement general adaptations instead of specific or substantial instructional adaptations. They also concluded that teachers with a more favorable disposition towards inclusion use more inclusive practices than those with less positive attitudes. Baker and Zigmond (1995) conducted five case studies to examine the effects of inclusion on students with disabilities in regular classes and reported that despite the fact that inclusive programs offered opportunities to enhance a students' educational level, teachers seldom used individualized teaching to attend to students' special needs. Other studies (e.g., McIntosh, Vaughn, Schumm, Haager, \& Lee, 1993; Vaughn \& Schumm, 1994) have also shown that teachers tend to plan and teach for the class as a whole, without attending to individual needs.

Research literature generally confirms that there is a great deal of teacher resistance to differentiate teaching and that there are a series of factors, such as teacher training, the grade level they teach, or the amount of support they receive (Biddle, 2006; McLeskey \& Waldron, 2002) which can determine this teacher behavior. For instance, teachers find some difficulties in implementing inclusive practices in their classrooms because of a lack of skills (Semmel, Abernathy, Butera, \& Lesar, 1991) and low selfefficacy (Bender, Vail, \& Scott, 1995). Teachers also feel ill-prepared and think they do not have the skills and training to teach students with SENs. However, when mainstream teachers feel confident and efficient to differentitate instruction, then benefits in students’ learning become evident (Simmons, Kame’enui, \& Chard, 1998). Other factors which may affect teacher resistance to use inclusive practices are grade level taught, and availability of resources and support. For instance, Ysseldyke, Thurlow, Wotruba, and Nania (1990) showed that elementary school teachers were more able to adapt instruction than secondary education teachers, and the former adapted instruction more frequently than high school teachers (Cardona, 2003b; McIntosh et al. 1993). Finally, research literature also supports the idea that a teachers' 
acceptance of instructional adaptations is related to the level of support he or she receives from the administration and the school (Scott, Vitale, \& Masten, 1998). Werts, Woley, Zinder, Caldwell, and Salisbury (1996) highlighted the existence of a positive relationship between the quantity and quality of support and resources, and the use of instructional adaptations. Teachers keep requesting more time, personal support, and material resources to address students' special educational needs (Hughes \& Martínez Valle-Riestra, 2007; Schumm et al., 1995). In fact, teachers think inclusion works when they received enough support and help from a special education teacher (Hughes \& Martínez Valle-Riestra, 2007).

Research on instructional adaptations for inclusion has certainly been scarce in Spain. A theoretical body regarding curricular adaptations was developed (González Manjón, 1993; Garrido Landívar, 1998; García Vidal, 1999), but little is known about the practices teachers actually carry out in their classrooms. An exception can be found in Cardona's studies about teachers' use of general and specific instructional adaptations (Cardona, 2002), and their perceptions about these strategies (Cardona, 2003a, 2003b). Findings from these studies indicate a moderate acceptance of instructional adaptations, but we lack knowledge as to whether these strategies differ as a function of grade level taught, training, and the availability of resources and support. Teachers in Spain adapt little for student diversity and when they do, they prefer those which require low effort, and which can be implemented for a large number of students. Typically, they undertake routine adaptations (e.g., variations in materials, classroom management, students motivation), strategies which will not significantly alter their usual practices (Cardona \& Chiner, 2006).

An in-depth analysis of the factors that may be promoting or hindering the implementation of these practices is relevant as it will help administrators, schools and universities to make better decisions to achieve more inclusive schools and classrooms. For this reason, the purpose of this study was to examine teachers' use of inclusive practices to respond to student diversity and how the implementation of these practices varies as a function of key variables such as the grade level they teach, their years of teaching, and the support they receive. In accordance with this purpose, the following research questions emerged: 
- To what extent do teachers from the province of Alicante use inclusive practices and which specific strategies do they use more frequently?

- Does the use of inclusive practices vary depending on grade level taught?

- Does the use of inclusive practices vary depending on teacher training?

- Does the use of inclusive practices vary depending on the resources and support teachers receive?

\section{Method}

\section{Participants}

The sample consisted of 336 general education teachers randomly selected from schools in the province of Alicante, Spain. First, stratified sampling procedures were used, taking the school circumscription (L’Alacantí-Alt/Mitjà Vinalopó, Baix Vinalopó-Baix Segura, Alcoià/Comtat-Les Marines) and the type of school (urban, suburban and rural) as strata to draw a sample of 78 schools which represented $27 \%$ of all the public schools of the whole province. In a second stage of the sampling procedure, two teachers of each grade level (kindergarten, elementary, and secondary education) were drawn from the 78 participating schools.

Of the 336 respondents, a total of 109 were male (33\%) and 221 were female (67\%). Their age ranged between 23 and $64(M=41.5, S D=8.65)$. Sixty-eight of the participating teachers (20.2\%) were teaching kindergarten; 133 (39.6\%), elementary education; and 135 (40.2\%) secondary education. Demographic data also showed that $51.3 \%(n=172)$ of the respondents had over 15 years of teaching experience; 69 (20.6\%) between 9 to 15 years; 55 (16.4\%) between 4 and 8 years; and 39 (11.6\%) of the respondents had 3 or less years of teaching experience. Their years of experience in special education were no significant $(M=.19, S D=1.01)$. All the respondent teachers had at least 1-2 students with special educational needs included in their classrooms.

Teachers participating in the study were mainly female (90\% kindergarten, $70 \%$ elementary, and 53\% secondary schools), while the number of male teachers was higher in secondary education (47\%) compared to $10 \%$ in kindergarten and $30 \%$ in elementary education. Most of the teachers in kindergarten (94\%) and elementary schools (91\%) had a bachelor degree, while in secondary education 36\% had a master's degree. Only two had a PhD or other degrees (3\%). Regarding years of teaching experience, 37\% of 
kindergarten teachers had taught more than 15 years, so did $69 \%$ of elementary and $42 \%$ of secondary teachers, respectively (Table 1).

Table 1. Participant teachers' demographic data by grade level

\begin{tabular}{|c|c|c|c|c|c|c|}
\hline & \multicolumn{2}{|c|}{ Kindergarten } & \multicolumn{2}{|c|}{ Elementary } & \multicolumn{2}{|c|}{ Secondary } \\
\hline & $f$ & $\%$ & $f$ & $\%$ & $f$ & $\%$ \\
\hline \multicolumn{7}{|l|}{ Gender } \\
\hline Male & 7 & 10.0 & 39 & 30.0 & 63 & 47.0 \\
\hline Female & 61 & 90.0 & 89 & 70.0 & 71 & 53.0 \\
\hline \multicolumn{7}{|l|}{ Education Degree } \\
\hline Bachelor & 63 & 94.0 & 121 & 91.0 & 81 & 60.0 \\
\hline Master & 4 & 6.0 & 11 & 8.3 & 49 & 36.0 \\
\hline Doctorate & & & & & 2 & 1.5 \\
\hline Other degrees & & & & & 2 & 1.5 \\
\hline No answer & & & 1 & .8 & 1 & 1.0 \\
\hline \multicolumn{7}{|c|}{ Years of teaching experience } \\
\hline $0-3$ & 9 & 13.0 & 11 & 8.0 & 19 & 14.0 \\
\hline $4-8$ & 12 & 18.0 & 9 & 7.0 & 34 & 25.0 \\
\hline $9-15$ & 22 & 32.0 & 22 & 16.0 & 25 & 19.0 \\
\hline+15 & 25 & 37.0 & 91 & 69.0 & 56 & 42.0 \\
\hline
\end{tabular}

\section{Instruments}

The Instructional Adaptations Scale (Cardona, 2000) was used to measure how frequently teachers implemented inclusive practices to address students' special needs. Previous research showed a good reliability of the instrument with an alpha coefficient of .90 and adequate content validity (Cardona, 2003a). The scale consisted of 21 items regarding a variety of inclusive practices. The participants had to respond how frequently they used each of those practices, using a five-point Likert scale ( 1 = never; 2 = seldom; 3 = occasionally; 4 = often; 5 = always). An exploratory factor analysis revealed four components, explaining $42.83 \%$ of the variance. The instrument was organized according to these factors: (1) Classroom Management Strategies (8 items), (2) Teaching and Assessment Strategies (4 items), (3) Grouping Strategies (5 items), and (4) Strategies to Adapt Tasks and Activities (4 items).

\section{Procedures}

The instrument was distributed personally to each of the 78 participating schools, with the collaboration of the CEFIREs (Centres of Training, Innovation, and Teaching Resources) of the province of Alicante which handed out the documents in each of the 
selected schools. Along with the instruments, two cover letters were included, one for the school principal and another one for the teachers participating in the investigation. Both letters described the purpose and relevance of the study, invited teachers to participate, and guaranteed the confidentiality of the information provided by the respondents. After two weeks, two members of each of the CEFIREs collected all the responded surveys and extended the return date one more week for those who had not yet responded.

\section{Data Analysis}

Measures of central tendency and dispersion were used to describe teacher training, the availability of resources and support, and the use of inclusive practices. One-way between groups analysis of variance (ANOVA) were used to determine differences in teachers' use of inclusive practices based on grade level taught, training, and availability of resources and support. To further determine the magnitude of differences, all comparisons were tested at the $p<.05$ significance level.

\section{Results}

\section{Teachers' use of inclusive practices}

As Table 2 shows, teachers in Spain only moderately use inclusive practices ( $M=3.49$, $S D=.42$ ). Teaching and Assessment Strategies were the strategies more frequently used $(M=4.07, S D=.62)$, followed by Classroom Management Strategies $(M=3.59, S D=$ $.64)$, while Grouping Strategies $(M=2.88, S D=.52)$ were the practices used the least.

To determine which specific practices respondents implemented more or less frequently, items over and under 1 standard deviation (.42) of the average scale $(M=$ 3.49) were selected (Table 2). Strategies more frequently used (often or always) by respondent teachers were the establishment of rules and routines in their classrooms (76\%), and all the strategies related with Teaching and Assessment, such as teaching students how to learn (69\%), motivating (81\%), monitoring and keeping a report of students' progress (87\%) or checking the curriculum objectives for adequate level of difficulty (86\%). On the other hand, teachers barely used practices such as taking more time to teach difficult concepts and procedures (34\%), grouping some students (4\%) or the whole class (14\%) in pairs, and using alternative materials (20\%). 
Regarding Classroom Management Strategies, the practice most frequently used was the establishment of rules and routines in the classroom (Item 1) with a mean of $4.20(S D=.91)$, while Item 4 (taking time to re-teach difficult concepts and procedures) was the least frequently used practice $(M=2.93, S D=1.15)$. In fact, only $34 \%$ of the respondents took the necessary time to re-teach difficult concepts and procedures.

Relating to Teaching and Assessment Strategies $(M=4.07, S D=.62)$, all the practices were often used by the respondents. Strategies such as seeking students' attention $(M=4.13, S D=.85)$, motivating $(M=4.23, S D=.84)$ ), monitoring and keeping a record of students' progress $(M=4.44, S D=.80)$, and checking curriculum objectives for adequate level of difficulty $(M=4.36, S D=.85)$ were used frequently, with the exception of teaching strategic learning procedures $(M=3.02, S D=1.14)$ that only a third (32\%) reported using this practice.

Grouping students to better learn was an infrequent strategy, particularly putting students to work in pairs $(M=1.66, S D=.77)$, where only $4 \%$ of the respondent teachers used this practice often / always.

Finally, the use of Strategies to Adapt Tasks and Activities were only occasionally used. For example, 26\% of the respondents never / seldom propose activities for diverse domain levels $(M=3.36, S D=1.09)$ and approximately half of the respondents prepare different kinds of activities $(M=2.76, S D=1.07)$ or use alternative materials $(M=2.63, S D=1.09)$.

Table 2. Use of inclusive practices by general education teachers

\begin{tabular}{|c|c|c|c|c|c|}
\hline & $M$ & $S D$ & $\begin{array}{c}\mathrm{N} / \mathrm{S} \\
\%\end{array}$ & $\begin{array}{c}\text { OC } \\
\%\end{array}$ & $\begin{array}{c}\mathrm{O} / \mathrm{A} \\
\%\end{array}$ \\
\hline \multicolumn{6}{|l|}{ Classroom Management Strategies } \\
\hline 1. I establish rules and routines in my class. & 4.20 & .91 & 4 & 20 & 76 \\
\hline 2. I teach to the whole class. & 3.12 & 1.07 & 33 & 30 & 37 \\
\hline $\begin{array}{l}\text { 3. When planning, I take into account the whole class } \\
\text { as well as the SE student needs. }\end{array}$ & 3.05 & 1.18 & 40 & 23 & 37 \\
\hline $\begin{array}{l}\text { 4. I take time to re-teach difficult concepts and } \\
\text { procedures. }\end{array}$ & 2.93 & 1.15 & 44 & 22 & 34 \\
\hline Total & 3.59 & .64 & & & \\
\hline \multicolumn{6}{|l|}{ Teaching and Assessment Strategies } \\
\hline 5. I show my students how to learn. & 3.99 & .98 & 8 & 23 & 69 \\
\hline
\end{tabular}


6. I use different strategies to seek their attention while I teach.

$\begin{array}{lllll}4.13 & .85 & 4 & 20 & 76\end{array}$

7. I motivate them.

$\begin{array}{lllll}4.23 & .84 & 4 & 15 & 81\end{array}$

8. I teach them strategic learning procedures.

$\begin{array}{lllll}3.02 & 1.14 & 36 & 32 & 32\end{array}$

9. I verify previous concepts and skills.

$\begin{array}{lllll}4.10 & .92 & 6 & 20 & 74\end{array}$

10. I monitor and keep a record of their progress.

$\begin{array}{lllll}4.44 & .80 & 3 & 10 & 87\end{array}$

11. I take into account the assessment results to plan

4.34

.87

5

10

85 new lessons.

12. I check curriculum objectives for adequate level of

4.36

.85

4

10

86 difficulty.

Total

$4.07 \quad .62$

\section{Grouping Strategies}

13. I teach individually, at certain times, some of my students.

$\begin{array}{lllll}3.70 & 1.07 & 18 & 23 & 59 \\ 3.27 & 1.07 & 28 & 32 & 40\end{array}$

14. I group my students using homogeneous and heterogeneously grouping strategies.

15. I put only some of my students to work in pairs.

$\begin{array}{lllll}1.66 & .77 & 88 & 8 & 4\end{array}$

16. I put all my students to work in pairs.

$\begin{array}{lllll}2.20 & 1.08 & 69 & 17 & 14\end{array}$

17. I adjust the classroom physical space depending on the activities.

Total

$2.88 \quad .52$

\section{Strategies to Adapt Tasks and Activities}

18. I split tasks/activities into more simple sequences.

$\begin{array}{llllll}\text { 19. I propose activities for diverse domain levels. } & 3.49 & 1.04 & 20 & 28 & 52 \\ & 3.36 & 1.09 & 26 & 29 & 45 \\ \begin{array}{l}\text { 20. I prepare different kind of activities to be done } \\ \text { simultaneously. }\end{array} & 2.76 & 1.07 & 49 & 25 & 26 \\ & & & & & 26 \\ \text { 21. I use alternative materials. } & 2.63 & 1.09 & 54 & 20 \\ \text { Total } & \mathbf{3 . 0 4} & \mathbf{. 7 5} & & \end{array}$

N/S = Never/Seldom (scores 1 and 2); OC = Occasionally (score 3); O/A = Often/Always (scores 4 and 5)

\section{Differences in use of inclusive practices depending on grade level taught}

Statistically significant differences were found in the implementation of inclusive practices when analyzed as a function of grade level taught (Table 3). Differences were 
found in 13 out of the 21 practices included in the instrument. Most of these statistically significant differences showed that kindergarten and elementary school teachers adapt for inclusion more often than secondary education teachers. For instance, teachers from lower grade levels (a) established rules and routines in their classes $(p<.01)$; (b) took into account both the whole class and students' SENs when planning $(p<.05$ ); (c) used different statregies to seek students' attention ( $p<.01)$; (d) motivated their students $(p<$ .01 ); and (e) used alternative materials more frequently than secondary education teachers $(p<.05)$. However, the latter ones more often implemented grouping strategies to work in pairs than their colleagues from kindergarten and elementary education levels $(p<.01)$.

\section{Differences in use of inclusive practices depending on teacher training, and the availability of resources and support}

Results showed (Table 4) that respondents rated low when they were asked about their skills and the availability of resources to attend to student diversity $(M=2.34, S D=$ 1.05). In fact, $80 \%$ of the respondents thought they do not have enough material resources to meet their students' special needs, while only $28 \%$ of the participants thought that they have enough training to address their students' needs. Teachers scored slightly higher regarding personal support, but still considered they were insufficient ( $M$ $=2.86, S D=1.11$ ). Thirty-nine percent asserted that the help they received from a special education teacher was not enough and $48 \%$ thought that the support of a school psychologist was insufficient as well. 
Table 3. Use of inclusive practices based on grade level taught

\begin{tabular}{|c|c|c|c|c|c|c|c|c|c|c|}
\hline \multirow[b]{2}{*}{ Classroom Management Strategies } & \multicolumn{2}{|c|}{ Kindergarten } & \multicolumn{2}{|c|}{ Elementary } & \multicolumn{2}{|c|}{ Secondary } & \multirow[b]{2}{*}{$\boldsymbol{F}$} & \multirow[b]{2}{*}{$d f$} & \multirow[b]{2}{*}{$p$} & \multirow[b]{2}{*}{ Direction $^{1}$} \\
\hline & $M$ & $S D$ & $M$ & $S D$ & $M$ & $S D$ & & & & \\
\hline 1. I establish rules and routines in my class. & 4.65 & .64 & 4.12 & .90 & 4.04 & .96 & 11.22 & 2 & $.000^{*}$ & $\mathrm{~K}>\mathrm{E}, \mathrm{S}$ \\
\hline 2. I teach to the whole class. & 3.25 & 1.07 & 3.07 & 1.08 & 3.10 & 1.06 & .61 & 2 & .543 & \\
\hline $\begin{array}{l}\text { 3. When planning, I take into account the whole class as } \\
\text { well as the SE student needs. }\end{array}$ & 3.35 & 1.14 & 3.09 & 1.18 & 2.86 & 1.16 & 3.88 & 2 & $.022 * *$ & $\mathrm{~K}>\mathrm{S}$ \\
\hline 4. I take time to re-teach difficult concepts and procedures. & 2.87 & 1.21 & 2.83 & 1.20 & 3.07 & 1.07 & 1.37 & 2 & .254 & \\
\hline \multicolumn{11}{|l|}{ Teaching and Assessment Strategies } \\
\hline 5. I show my students how to learn. & 3.94 & 1.22 & 4.11 & .90 & 3.89 & .92 & 1.88 & 2 & .154 & \\
\hline $\begin{array}{l}\text { 6. I use different strategies to seek their attention while I } \\
\text { teach. }\end{array}$ & 4.49 & .68 & 4.03 & .81 & 4.05 & .92 & 7.76 & 2 & $.001 *$ & $\mathrm{~K}>\mathrm{E}, \mathrm{S}$ \\
\hline 7. I motivate them. & 4.67 & .53 & 4.19 & .84 & 4.05 & .89 & 13.47 & 2 & $.000 *$ & $\mathrm{~K}>\mathrm{E}, \mathrm{S}$ \\
\hline 8. I teach them strategic learning procedures. & 3.06 & 1.17 & 3.25 & 1.12 & 2.76 & 1.09 & 6.27 & 2 & $.002 *$ & $\mathrm{E}>\mathrm{S}$ \\
\hline 9. I verify previous concepts and skills. & 4.33 & .78 & 4.22 & .87 & 3.87 & .98 & 7.57 & 2 & $.001 *$ & $\mathrm{~K}, \mathrm{E}>\mathrm{S}$ \\
\hline 10. I monitor and keep a record of their progress. & 4.38 & .82 & 4.45 & .82 & 4.45 & .78 & .19 & 2 & .824 & \\
\hline $\begin{array}{l}\text { 11. I take into account the assessment results to plan new } \\
\text { lessons. }\end{array}$ & 4.51 & .74 & 4.38 & .84 & 4.21 & .95 & 3.01 & 2 & .050 & \\
\hline $\begin{array}{l}\text { 12. I check curriculum objectives for adequate level of } \\
\text { difficulty }\end{array}$ & 4.44 & .76 & 4.38 & .87 & 4.31 & .87 & .62 & 2 & .536 & \\
\hline
\end{tabular}




\section{Grouping Strategies}

13. I teach individually, at certain times, some of my students.

14. I group my students using homogeneous and

heterogeneously grouping strategies.

15. I put only some of my students to work in pairs.

16. I put all my students to work in pairs.

17. I adjust the classroom physical space depending on the activities.

$\begin{array}{llllllllll}\mathbf{4 . 0 6} & .82 & \mathbf{3 . 8 7} & 1.02 & \mathbf{3 . 3 7} & 1.15 & 12.61 & 2 & \mathbf{. 0 0 0} * & \mathrm{~K}, \mathrm{E}>\mathrm{S} \\ \mathbf{3 . 8 5} & .96 & \mathbf{3 . 3 0} & 1.04 & \mathbf{2 . 9 2} & 1.01 & 18.81 & 2 & \mathbf{. 0 0 0} * & \mathrm{~K}>\mathrm{E}>\mathrm{S} \\ \mathbf{1 . 4 3} & .53 & \mathbf{1 . 6 6} & .81 & \mathbf{1 . 7 8} & .82 & 4.42 & 2 & \mathbf{. 0 1 3 * *} & \mathrm{S}>\mathrm{K} \\ \mathbf{1 . 6 6} & .81 & \mathbf{2 . 1 6} & 1.04 & \mathbf{2 . 5 2} & 1.12 & 15.14 & 2 & \mathbf{. 0 0 0 *} & \mathrm{S}>\mathrm{E}>\mathrm{K} \\ \mathbf{4 . 3 4} & .77 & \mathbf{3 . 6 8} & 1.13 & \mathbf{3 . 3 0} & 1.20 & 20.08 & 2 & \mathbf{. 0 0 0 *} & \mathrm{K}>\mathrm{E}>\mathrm{S} \\ & & & & & & & & & \\ \mathbf{3 . 4 9} & 1.05 & \mathbf{3 . 5 7} & 1.08 & \mathbf{3 . 4 1} & .99 & .81 & 2 & 0.444 & \\ \mathbf{3 . 4 8} & 1.12 & \mathbf{3 . 4 6} & 1.11 & \mathbf{3 . 2 0} & 1.04 & 2.53 & 2 & 0.081 & \\ \mathbf{3 . 1 1} & 1.17 & \mathbf{2 . 8 6} & 1.05 & \mathbf{2 . 4 9} & .98 & 8.49 & 2 & \mathbf{. 0 0 0 *} & \mathrm{K}, \mathrm{E}>\mathrm{S} \\ & & & & & & & & & \\ \mathbf{2 . 7 0} & .98 & \mathbf{2 . 7 8} & 1.15 & \mathbf{2 . 4 4} & 1.05 & 3.26 & 2 & \mathbf{. 0 4 0 * *} & \mathrm{E}>\mathrm{S}\end{array}$

Strategies to Adapt Tasks and Activities

18. I split tasks/activities into more simple sequences.

19. I propose activities for diverse domain levels.

20. I prepare different kind of activities to be done simultaneously.

21. I use alternative materials

* Significant at $p<.01$ level

** Significant at $p<.05$ leve

${ }^{1} \mathrm{~K}$ = Kindergarten; $\mathrm{E}=$ Elementary Education; $\mathrm{S}$ = Secondary Education 
Table 4. Teacher training and availability of resources and support

\begin{tabular}{|c|c|c|c|c|c|}
\hline & $M$ & $S D$ & $\begin{array}{c}\text { Disagree } \\
\% \\
\end{array}$ & $\begin{array}{c}\text { Undecided } \\
\% \\
\end{array}$ & $\begin{array}{c}\text { Agree } \\
\% \\
\end{array}$ \\
\hline \multicolumn{6}{|l|}{ Training and resources } \\
\hline $\begin{array}{l}\text { I have enough training to teach all my } \\
\text { students. }\end{array}$ & 2.72 & 1.18 & 49 & 23 & 28 \\
\hline $\begin{array}{l}\text { I have enough material resources to } \\
\text { attend my students' special needs. }\end{array}$ & 1.97 & .92 & 80 & 12 & 8 \\
\hline Total & 2.34 & 1.05 & & & \\
\hline \multicolumn{6}{|l|}{ Personal Supports } \\
\hline $\begin{array}{l}\text { I receive enough help from the special } \\
\text { education teacher. }\end{array}$ & 2.97 & 1.25 & 39 & 18 & 43 \\
\hline $\begin{array}{l}\text { I receive enough help from the school } \\
\text { psychologist. }\end{array}$ & 2.76 & 1.22 & 48 & 18 & 34 \\
\hline Total & 2.86 & 1.11 & & & \\
\hline
\end{tabular}

The subsequent analysis to determine differences in teachers' use of inclusive practices based on training and the availability of resources to attend to diversity indicated variations in the use of inclusive practices. No statistical differences were found, however, regarding the availability of personal support (special education teacher and school psychologist). Specifically, teachers whom believed that they had sufficient training used Teaching and Assessment Strategies more often than those teachers who felt ill-prepared (Table 5). Indeed, teachers with sufficient training to respond to student diversity $(M=4.24, S D=.86)$ showed their students how to learn more often than teachers with less skills $(M=3.75, S D=1.04)$. They also used strategic learning procedures $(M=3.26, S D=1.18)$ more frequently than teachers with insufficient training $(\mathrm{M}=2.87, S D=1.17)$. Other strategies such as monitoring students' progress $(p<.05)$, checking assessment results for planning $(p<.01)$, and checking curriculum objectives for an adequate level of difficulty $(p<.05)$ showed statistically significant differences as well. 
Table 5. Use of inclusive practices based on teacher training

\begin{tabular}{|c|c|c|c|c|c|c|c|c|c|c|}
\hline \multirow[b]{2}{*}{ Teaching and Assessment Strategies } & \multicolumn{2}{|c|}{ Sufficient } & \multicolumn{2}{|c|}{ Insufficient } & \multicolumn{2}{|c|}{$\begin{array}{l}\text { Neither suffic. / } \\
\text { nor insuffic. }\end{array}$} & \multirow[b]{2}{*}{$\boldsymbol{F}$} & \multirow[b]{2}{*}{$d f$} & \multirow[b]{2}{*}{$p$} & \multirow[b]{2}{*}{ Direction $^{1}$} \\
\hline & $M$ & $S D$ & $M$ & $S D$ & $M$ & $S D$ & & & & \\
\hline I show my students how to learn. & 4.24 & .86 & 3.75 & 1.04 & 4.16 & .88 & 9.34 & 2 & $.000 *$ & $\begin{array}{l}\mathrm{S}>\mathrm{I} \\
\mathrm{NS} / \mathrm{NI}>\mathrm{I}\end{array}$ \\
\hline I use different strategies to seek attention while I teach. & 4.12 & 0.89 & 4.09 & .84 & 4.22 & .83 & .60 & 2 & .549 & \\
\hline I motivate them. & 4.28 & .82 & 4.15 & .88 & 4.34 & .77 & 1.49 & 2 & .225 & \\
\hline I teach them strategic learning procedures. & 3.26 & 1.18 & 2.87 & 1.17 & 3.03 & .95 & 3.37 & 2 & $.036 * *$ & $\mathrm{~S}>\mathrm{I}$ \\
\hline I verify previous concepts and skills. & 4.24 & .83 & 4.03 & .98 & 4.10 & .86 & 1.55 & 2 & .213 & \\
\hline I monitor and keep a record of their progress. & 4.62 & .74 & 4.38 & .81 & 4.35 & .83 & 3.35 & 2 & $.036 * *$ & $\mathrm{~S}>\mathrm{I}, \mathrm{NS} / \mathrm{NI}$ \\
\hline $\begin{array}{l}\text { I take into account the assessment results to plan new } \\
\text { lessons. }\end{array}$ & 4.57 & .75 & 4.23 & .94 & 4.29 & .84 & 4.90 & 2 & $.008 *$ & $\mathrm{~S}>\mathrm{I}$ \\
\hline $\begin{array}{l}\text { I check curriculum objectives for adequate level of } \\
\text { difficulty }\end{array}$ & 4.56 & .68 & 4.25 & .95 & 4.35 & .77 & 3.98 & 2 & $.020 * *$ & $\mathrm{~S}>\mathrm{I}$ \\
\hline
\end{tabular}

* Significant at $p<.01$ level

** Significant at $p<.05$ level

${ }^{1} \mathrm{~S}=$ Sufficient; $\mathrm{I}=$ Insufficient; NS/NI = Neither sufficient nor insufficient 
Regarding the availability of resources, Table 6 clearly shows how teachers whom believed resources were sufficient, significantly implemented some Teaching and Assessment Strategies more often than respondents who thought that these resources were not enough. Teachers with sufficient resources used different strategies to seek for students' attention during instruction more frequently than teachers whom responded that the resources were neither sufficient nor insufficient $(p<.05)$. They also motivated their students more often than respondents who thought resources were not sufficient ( $p$ $<$.05). A similar tendency can be found in other two strategies: taking into account assessment results for planning $(p<.05)$ and checking curriculum objectives for an adequate level of difficulty $(p<.05)$.

\section{Discussion}

The purpose of this study was to examine the extent to which general education teachers from the province of Alicante, Spain, use inclusive practices to respond to students' diverse needs and to determine whether this use is influenced by grade level taught, teacher training, resources, and support. The investigation contributes to have a better knowledge of how teachers address diversity in their classrooms and, overall, to what extent students with SENs have the opportunity to fully participate in the classroom. Although the study was carried out with a representative sample of teachers of the province of Alicante, Spain, results should be considered cautiously. Findings are from a specific geographical area, and the inclusive practices teachers use may not reflect teacher's practices from other provinces or regions. Furthermore, the responses of participants may not be accurate and may reflect socially desirable responses rather than their real practices. For this reason, it would be convenient to conduct direct observations inside the classrooms to contrast what teachers say about using instructional adaptations and what they actually do in their classes. Finally, the inclusive practices included in the Instructional Adaptations Scale are not the only practices teachers can implement to respond to student's educational needs and we need to bear in mind that teachers may be using other practices that also help to enhance students' learning and achievement. 
Table 6. Use of inclusive practices based on availability of resources

\begin{tabular}{|c|c|c|c|c|c|c|c|c|c|c|}
\hline \multirow[b]{2}{*}{ Teaching and Assessment Strategies } & \multicolumn{2}{|c|}{ Sufficient } & \multicolumn{2}{|c|}{ Insufficient } & \multicolumn{2}{|c|}{$\begin{array}{l}\text { Neither suffic. / } \\
\text { nor insuffic. }\end{array}$} & \multirow[b]{2}{*}{$\boldsymbol{F}$} & \multirow[b]{2}{*}{$d f$} & \multirow[b]{2}{*}{$p$} & \multirow[b]{2}{*}{ Direction $^{1}$} \\
\hline & $M$ & $S D$ & $M$ & $S D$ & $M$ & $S D$ & & & & \\
\hline I show my students how to learn. & 4.11 & 1.03 & 3.95 & .99 & 4.14 & .88 & .77 & 2 & .461 & \\
\hline I use different strategies to seek attention while I teach. & 4.50 & .79 & 4.12 & .85 & 3.93 & .82 & 3.87 & 2 & $.022 *$ & $\mathrm{~S}>\mathrm{NS} / \mathrm{NI}$ \\
\hline I motivate them. & 4.64 & .67 & 4.18 & .84 & 4.25 & .87 & 3.83 & 2 & $.023 *$ & $\mathrm{~S}>\mathrm{I}$ \\
\hline I teach them strategic learning procedures. & 3.18 & 1.27 & 3.00 & 1.13 & 3.06 & 1.09 & .34 & 2 & .710 & \\
\hline I verify previous concepts and skills. & 4.32 & .81 & 4.06 & .95 & 4.21 & .74 & 1.28 & 2 & .279 & \\
\hline I monitor and keep a record of their progress. & 4.64 & .78 & 4.42 & .81 & 4.44 & .78 & 1.00 & 2 & .366 & \\
\hline $\begin{array}{l}\text { I take into account the assessment results to plan new } \\
\text { lessons. }\end{array}$ & 4.75 & .70 & 4.28 & .89 & 4.48 & .78 & 4.31 & 2 & $.014 *$ & $\mathrm{~S}>\mathrm{I}$ \\
\hline $\begin{array}{l}\text { I check curriculum objectives for adequate level of } \\
\text { difficulty }\end{array}$ & 4.75 & .51 & 4.30 & .89 & 4.51 & .68 & 4.24 & 2 & $.015 *$ & $\mathrm{~S}>\mathrm{I}$ \\
\hline
\end{tabular}

* Significant at $p<.05$ level

${ }^{1} \mathrm{~S}=$ Sufficient; I = Insufficient; NS/NI = Neither sufficient nor insufficient 


\section{Teachers' use of inclusive practices}

Findings in this study suggest teachers moderately use inclusive practices $(M=3.44, S D$ $=.43$ ) and whenever they used them, teachers implemented general adaptations more often than substantial ones. Teaching and assessment strategies (e.g., motivating students, monitoring and keeping a record of their students' progress, verifying students’ previous knowledge of concepts and skills) were used more frequently by teachers from the province of Alicante than other sets of inclusive practices. All of those practices are easy to implement in order to plan and teach the whole group and require little extra work. However, more specific practices such as the adaptation of activities and grouping strategies were implemented less frequently, despite previous research that states that these practices are effective in promoting the inclusion of students with SENs (Cook \& Friend, 1995; Thousand, Villa, \& Nevin, 2002). Therefore, these results support the general idea that teachers adapt little for instruction. They prefer to implement general strategies that demand little effort and time rather than specific curricular adaptations oriented to meet particular students' needs (Baker \& Zigmond, 1995; Cardona, 2003a, 2003b; Cardona \& Chiner, 2006; McInstosh et al., 1993).

\section{Influence of grade level taught on teachers' use of inclusive practices}

Grade level taught led to significant differences in teachers' use of instructional adaptations. Kindergarten and elementary educators used practices such as motivating, seeking students' attention, establishing rules and routines, adjusting classroom physical space, etc., more frequently than secondary education teachers. These findings are consistent with previous works (Cardona, 2003a; McIntosh et al., 1993; Ysseldyke et al., 1990) which have shown that teachers of lower grade levels are more capable of making instructional adaptations than secondary educators. They also support the idea that secondary education teachers do not have the skills to adapt instruction. This is an important issue to be considered by the universities and the design of teacher education programs in order to offer more pre-service and in-service training that will help teachers to improve their skills and address efficiently students' educational needs.

Teachers' use of inclusive practices based on training, and the availability of resources and supports 
Results from this study show that training makes a significant difference in a teachers' implementation of inclusive practices. The more training they have, the more practices they use. This is consistent with other studies (Hughes \& Martínez Valle-Riestra, 2007; McLeskey \& Waldron, 2002; Zhang, 2006) which state that teachers feel ill-prepared to use effective inclusive practices and those with more training tend to implement them more frequently. Training and practice are highly related and the lack of knowledge about some strategies is keeping teachers from using them, preferring those accommodations which are easy to implement because they know how to use them.

Differences were also found regarding the availability of resources. Teachers whom think they have sufficient material resources to address students' educational needs use inclusive practices more often than teachers who consider resources to be insufficient. These findings support those from Schumm et al. (1995), and Scott, Vitale, and Masten (1998) which suggested that resources are an important factor to carry out adaptations in inclusive classrooms. The support of other professionals, however, did not show significant differences in teachers' implementations of inclusive practices. This might mean that the amount of support teachers receive from the special educator and the school psychologist might not significantlly affect their use of inclusive practices.

\section{Conclusions}

Differentiation and instructional adaptations are on the basis of inclusive education and those strategies are considered to be key conditions for its success (Giangreco, 1997; McLeskey \& Waldron, 2002). Findings from this study have helped identify under which conditions teachers use inclusive practices, as well as the most and least practices they use. General education teachers are hesitant to implement them perhaps because they do not know how to use them. Teachers would certainly use more inclusive practices in their classrooms if they were trained in new strategies to address the new demands of education and were provided with the resources and support to cope with them. Special attention should be paid to secondary education teachers whose knowledge and skills to adapt for inclusion are scarce due to their specialized preservice training on one specific subject. These findings are a good starting point for school administrators to set the best conditions for inclusion, providing teachers with the tools and resources necessary to promote full participation by all the students. Moreover, pre-service and in-service training should provide teachers with the adequate 
skills to address students' learning needs by designing teacher education programs focused on giving teachers specific opportunities for learning to teach in diverse contemporary classrooms rather than in imaginary, homogeneous classrooms.

\section{Notes on contributors}

Dr. Esther Chiner is a lecturer of Special and Inclusive Education at the Faculty of Education, University of Alicante, Spain.

Dr. Maria Cristina Cardona is a professor of Special and Inclusive Education at the Faculty of Education, University of Alicante, Spain.

\section{References}

Baker, J.M. \& Zigmond, N. (1995). The meaning and practice of inclusion for students with learning disabilities: Themes and implications from the five cases. The Journal of Special Education, 29(2), 163-180.

Bender, W.N., Vail, C.O., \& Scott, K. (1995). Teachers' attitudes toward increased mainstreaming: Implementing effective instruction for students with learning disabilities. Journal of Learning Disabilities, 28(2), 87-94, 120.

Biddle, S. (2006). Attitudes in education. Assessing how teachers' attitudes about inclusion on learning disabled students affects their use of accommodations. The Science Teacher, 73(3), 52-56.

Booth, T. \& Ainscow, M. (1998). From them to us. London, England: Routledge.

Cardona, M.C. (2000). Escala de Adaptaciones de la Enseñanza. Forma General. Alicante: Servicio de Publicaciones, University of Alicante, Spain.

Cardona, M.C. (2002). Adapting instruction to address individual and group educational needs in maths. Journal of Research in Special Educational Needs, 2(1), 1-17.

Cardona, M.C. (2003a). Inclusión y cambios en el aula vía adaptaciones instructivas. Revista de Investigación Educativa, 21(2), 465-487.

Cardona, M.C. (2003b). Mainstream teachers' acceptance of instructional adaptations in Spain. European Journal of Special Needs Education, 18(3), 311-332.

Cardona, M.C., \& Chiner, E. (2006). Uso y efectividad de las adaptaciones instructivas en aulas inclusivas: un estudio de las percepciones y necesidades formativas del profesorado. Bordón, 58(3), 5-24. 
Cardona, M.C., Gómez-Canet, P.F., \& González-Sánchez, M.E. (2000). Cuestionario de Percepciones del Profesor acerca de una Pedagogía Inclusiva. Alicante: University of Alicante.

Chiner, E. (2011). Las percepciones y actitudes del profesorado hacia la inclusión del alumnado con necesidades educativas especiales como indicadores del uso de prácticas educativas inclusivas en el aula. Alicante, Spain: University of Alicante.

Cook, L. \& Friend, M. (1995). Co-teaching: Guideline for creating effective practices. Focus on Exceptional Children, 28, 1-12.

Daane, C.J., Beirne-Smith, M., \& Latham, D. (2000). Administrators' and teachers' perceptions of the collaborative efforts of inclusion in the elementary grades. Education, 121(2), 331-339.

Florian, L. (1998). Inclusive practice. What, why and how? In C. Tilstone, L. Florian, and R. Rose (Eds.), Promoting inclusive practice (13-26). London, England: Routledge.

Fuchs, L.S., Fuchs, D., Hamlett, C.L., Phillips, N.B., \& Karns, K. (1995). General educators' specialized adaptation for students with learning disabilities. Exceptional Children, 61(5), 440-459.

García Vidal, J. (1999). Guía para realizar adaptaciones curriculares. Madrid, Spain: EOS.

Garrido Landívar, J. (1998). Adaptaciones curriculares: guía para los profesores tutores de educación primaria y de educación especial. Madrid, Spain: CEPE.

Giangreco, M.F. (1997). Key lessons learned about inclusive education: summary of the 1996 Schonell Memorial Lecture. Journal of Applied Research in Intelectual Disabilities, 10(1), 1-14.

González Manjón, D. (1993). Adaptaciones curriculares. Guía para su elaboración. Málaga, Spain: Aljibe.

Hughes, M.T. \& Martínez Valle-Riestra, D. (2007). Experiences of kindergarten teachers implementing instructional practices for diverse learners. International Journal of Special Education, 22(2), 119-128.

McInstosh, R., Vaughn, S., Schumm, J.S., Haager, D., \& Lee, O. (1993). Observations of students with learning disabilities in general education classrooms. Exceptional Children, 60(3), 249-261. 
McLeskey, J. \& Waldron, N.L. (2002). School change and inclusive schools: Lessons learned from practice. Phi Delta Kappan, 84(1), 65.

Minke, K.M., Bear, G., Deemer, S.A., \& Griffin, S.M. (1996). Teachers’ experiences with inclusive classrooms: Implication for special education reform. Journal of Special Education, 30, 152-186.

Schumm, J.S., Vaughn, S., Haager, D., McDowell, J., Rothlein, L. \& Saumell, L. (1995). General education teacher planning: What can students with learning disabilities expect? Excepcional Children, 61(4), 335-352.

Scott, B.J., Vitale, M.R., \& Masten, W.G. (1998). Implementing instructional adaptations for students with disabilities in inclusive classrooms. A literature review. Remedial and Special Education, 19(2), 106-119.

Semmel, M.I., Abernathy, T.V., Butera, G., \& Lesar, S. (1991). Teacher perceptions of regular education initiative. Exceptional Children, 58(1), 9-24.

Schumm, J.S. \& Vaughn, S. (1991). Making adaptations for mainstreamed students: General classroom teachers’ perceptions. Remedial and Special Education, 12(4), 18-27.

Simmons, D.C., Kame’enui, E.J., \& Chard, D.J. (1998). General education teachers’ assumptions about learning and students with learning disabilities: Design-ofinstruction analysis. Learning Disability Quarterly, 21(1), 6-21.

Thousand, J.S., Villa, R.A., \& Nevin, A. (2002). Creativity and collaborative learning: The practical guide to empowering students, teachers and families. Baltimore: Paul H. Brookes.

Tomlinson, C.A., Callahan, C., Tomchin, C., Eiss, N., Imbeau, M., \& Landrum, M. (1997). Becoming architects of communities of learning: Addressing academic diversity in contemporary classrooms. Exceptional Children, 63(2), 269-282.

Vaughn, S. \& Schumm, J.S. (1994). Middle school teachers’ planning for students with learning disabilities. Remedial and Special Education, 15, 152-161.

Vaughn, S., Schumm, J.S., Jallad, B., Slusher, J., \& Saumell, L. (1996). Teachers’ views of inclusion. Learning Disabilities Practice, 11, 96-106.

Vlachou, A., Didaskalou, E. \& Voudouri, E. (2009). Adaptaciones en la enseñanza de los maestros de Educación General: repercusiones de las respuestas de inclusión. Revista de Educación, 349 (May-August), 179-201.

Werts, M.G., Woley, M., Zinder, E.D., Caldwell, N.K., \& Salisbury, C.L. (1996). Supports and resources associated with inclusive schooling: Perceptions of 
elementary school teachers about need and availability. The Journal of Special Education, 30, 187-203.

Ysseldyke, J.E., Thurlow, M., Wotruba, J.W., \& Nania, P.A. (1990). Instructional arrangements: Perceptions from general education. Teaching Exceptional Children, 22(4), 4-8.

Zhang, G. (2006). Teachers' perceptions of inclusion and their implementation of accommodations for students with disabilities in general education classrooms (Unpublished doctoral thesis). University of South Dakota. 